\title{
Variabel Makroekonomi Sebagai Determinan Saham Properti
}

\section{Adrianna Syariefur Rakhmat}

Program Studi Manajemen

Universitas Pelita Bangsa

Email: adriannasyariefur@yahoo.com

\begin{abstract}
ABSTRAK
Pertumbuhan penduduk yang tinggi dari tahun ke tahun menjadi salah satu penyebab berkembangnya sektor properti. Kondisi tersebut dapat menjadi pertimbangan masyarakat untuk investasi pada saham subsektor property dan real estate. Dalam keputusan berinvestasi, investor harus melihat kondisi ekonomi makro yang dapat mempengaruhi pergerakan harga saham. Tujuan dari penelitian ini adalah menganalisis mengenai pengaruh faktor ekonomi makro yaitu inflasi, suku bunga, dan nilai tukar rupiah terhadap harga saham property dan real estate.

Penelitian ini merupakan penelitian kuantitatif dengan metode analisis regresi data panel dan menggunakan software Eviews 10. Data yang digunakan adalah data bulanan yang diperoleh dari laporan bulanan Bursa Efek Indonesia, Bank Indonesia, dan Badan Pusat Statistik, dengan teknik mencatat atau dokumentasi. Teknik pengambilan sampel dilakukan secara purposive sampling dan mendapatkan 420 data selama periode 2014-2018 pada 7 perusahaan subsektor property dan real estate yang terdaftar di Bursa Efek Indonesia.

Hasil penelitian ini menunjukkan bahwa secara parsial, masing-masing variabel inflasi dan nilai tukar rupiah memiliki pengaruh negatif dan signifikan terhadap harga saham subsektor property dan real estate. Sedangkan variabel suku bunga memberikan pengaruh negatif namun tidak signifikan terhadap harga saham subsektor property dan real estate yang terdaftar di Bursa Efek Indonesia selama periode penelitian.
\end{abstract}

Kata Kunci: Inflasi, Suku Bunga, Nilai Tukar, Harga Saham.

\section{ABSTRACT}

High population growth from year to year is one cause of the development of the property sector. These can be considered by the public to invest in stock of the property and real estate subsector. In investing decisions, investors must look at macroeconomic conditions that can affect stock price movements. The puspose of this studying to analyze the effect of macroeconomic factors, namely inflation, interest rates, and the exchange rate of rupiah on the stock price of the property and real estate.

This research is a quantitative study using panel data regression analysis method and using software Eviews 10. The data used are monthly data obtained from monthly report of the Indonesia Stock Exchange, Bank Indonesia, and the Central Statistics Agency with the technique of recording or documentation. The sampling technique is done by purposive sampling and obtaining 420 data during 2014-2019 period in 7 property and real estate subsector companies listed on the Indonesia Stock Exchange.

The result of this study show partial result, each inflation variable and the rupiah exchange rate has a negative and significant effect on the share price of the property 
and real estate subsector. While the interest rate variable has a negative but not significant effect on the share price of the property and real estate subsector listed on the Indonesia Stock Exchange during the study period.

Keyword: Inflation, Interest Rate, Exchange Rates, Stock Price.

\section{PENDAHULUAN}

Sektor properti memiliki peran penting dalam mendorong perkembangan perekonomian nasional. Dalam pembangunan perumahan dan konstruksi, sektor properti dapat menyerap tenaga kerja dalam jumlah yang besar, misalnya seperti tenaga kasar atau buruh, arsitek, desainer, kontraktor, agen properti, notaris. Sektor ini juga memiliki efek berantai atau berdampak untuk mendorong perkembangan sektor ekonomi lainnya seperti industri bahan bangunan, konstruksi, dan sektor perbankan. Oleh karena itu, sektor ini telah mendorong ekonomi nasional dengan menciptakan lapangan pekerjaan dan menekan angka kemiskinan. Perkembangan subsektor property dan real estate di Indonesia memiliki prospek yang sangat luas. Pertambahan penduduk Indonesia dari tahun ke tahun menjadi salah satu alasan semakin pesatnya pertumbuhan sektor tersebut. Pertumbuhan penduduk di Indonesia menunjukkan angka yang semakin meningkat. Semakin banyaknya jumlah penduduk Indonesia merupakan peluang yang besar bagi perusahaan properti. Kebutuhan masyarakat akan property dan real estate seperti tempat hunian, kawasan industri, kawasan komersil, menjadi ladang bisnis bagi para pengembang properti.

Selain itu peningkatan jumlah penduduk juga akan meningkatkan jumlah permintaan pembangunan terhadap apartemen, pusat perbelanjaan, dan tempat umum lainnya. Hal ini akan berimbas pada sektor property dan real estate yang semakin berkembang yang nantinya mempengaruhi kegiatan ekonomi dan perkembangan ekonomi nasional. Kondisi ini akan menjadi pertimbangan masyarakat untuk berinvestasi pada sektor tersebut, khususnya investasi pada saham properti. Namun, beberapa tahun terakhir ini harga saham sektor properti sedang mengalami penurunan. Menurunnya harga saham sektor properti dapat dilihat secara global dari penurunan indeks harga saham sektor properti di Bursa Efek Indonesia. 


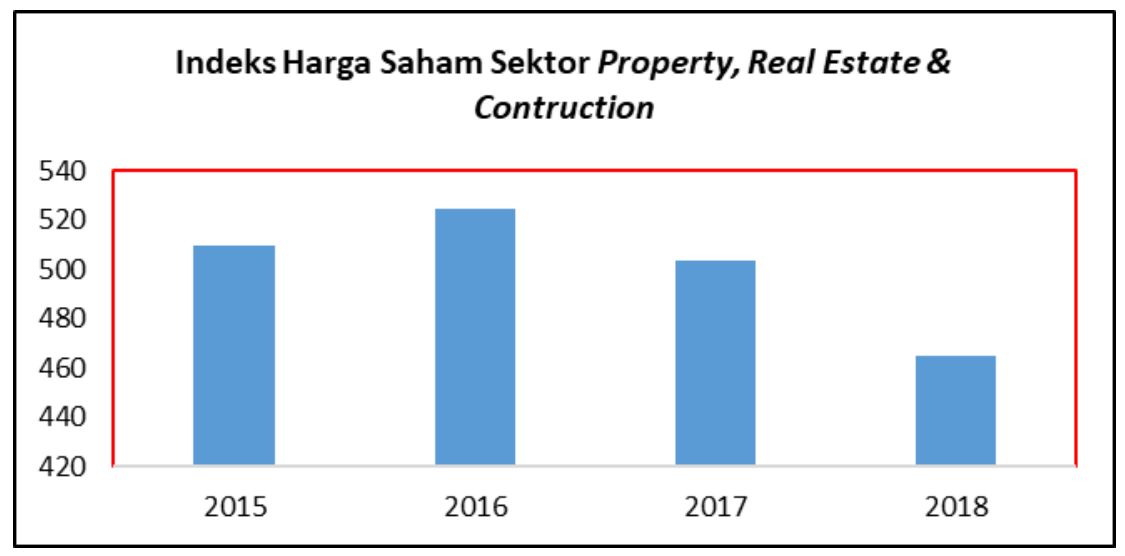

Sumber: Yahoo Finance, data diolah penulis, 2019.

Gambar 1: Indeks Harga Saham Sektor Properti, Real Estate dan Konstruksi

Pergerakan harga saham sektor properti pada tahun 2015-2018 sedang mengalami penurunan seperti yang terlihat pada tabel di atas. Hal ini bisa menjadi dampak berkepanjangan dari krisis ekonomi global, dan beberapa faktor lain seperti faktor ekonomi makro, permintaan konsumen yang menurun, dan lain sebagainya.

Menurut Simbolon (2018) beberapa faktor ekonomi makro yang dapat mempengaruhi pergerakan harga saham adalah laju inflasi, suku bunga, dan nilai tukar rupiah. Faktor yang pertama adalah inflasi. Inflasi adalah kondisi di mana adanya kenaikan harga barang secara umum dan secara terus-menerus. Kondisi inflasi yang tidak stabil menghambat masyarakat dalam mengambil keputusan investasi. Dampak inflasi juga mengakibatkan penurunan daya beli masyarakat terhadap pembelian instrumen saham. Pendapatan masyarakat yang tidak sebanding dengan kenaikan harga kebutuhan, membuat masyarakat semakin berhemat dan tidak tertarik dalam membeli saham.

Tingkat suku bunga juga merupakan faktor ekonomi makro yang dapat mempengaruhi naik-turunnya harga saham. Jika tingkat suku bunga rendah, maka masyarakat akan banyak membeli barang-barang seperti mobil, rumah, dan sebagainya, karena mereka dapat membiayai pembelian tersebut pada tingkat suku bunga yang rendah. Kondisi seperti itu, akan membuat pendapatan perusahaan meningkat, dan investor akan berlomba membeli saham perusahaan tersebut sehingga harga saham akan naik. 
Faktor ekonomi makro selanjutnya yang dapat mempengaruhi harga saham adalah nilai tukar rupiah. Pelemahan rupiah sangat berdampak bagi emiten atau perusahaan yang memiliki beban hutang dalam bentuk dollar Amerika, dan perusahaan yang melakukan impor dari luar negeri. Karena, dengan merosotnya nilai tukar rupiah, maka menjadi penyebab jumlah hutang perusahaan impor dan biaya produksi menjadi lebih besar jika dinilai dengan rupiah.

Salah satu penelitian hubungan antara inflasi, nilai tukar, dengan harga saham adalah penelitian yang dilakukan oleh Budiantara (2012) menyatakan bahwa inflasi berpengaruh positif signifikan terhadap saham. Jayanti (2014) juga mengatakan hal yang sama dalam penelitiannya. Namun, Rosalyn (2018) dalam penelitiannya menunjukkan bahwa inflasi berpengaruh negatif signifikan terhadap harga saham.

Penelitian selanjutnya tentang hubungan antara suku bunga dengan harga saham dilakukan oleh Mardiyati dan Rosalina (2013) mengatakan bahwa suku bunga berpengaruh positif tidak signifikan. Namun hasil penelitian Efni (2009) dan Simbolon (2018) menyatakan suku bunga berpengaruh negatif signifikan terhadap harga saham.

Rudi dan Muamil (2018) dalam penelitiannya menunjukkan hubungan positif signifikan antara nilai tukar dengan harga saham. Namun, penelitian Wijaya (2013) menyatakan bahwa nilai tukar berpengaruh negatif signifikan terhadap harga saham. Hasil penelitian serupa juga dinyatakan oleh Worokinasih dan Harsono (2018).

\section{LITERATUR DAN HIPOTESIS}

\subsection{Inflasi}

Laju Inflasi yang stabil mencerminkan sistem perekonomian negara yang sehat. Natsir (2014) mengemukakan Inflasi adalah suatu kondisi meningkatnya harga-harga barang dan jasa secara umum dan terus menerus. Untuk mengukur laju inflasi, terdapat beberapa indeks harga yang digunakan menurut Rahardja dan Manurung (2008) yaitu:

a. Indeks Harga Konsumen atau IHK, yaitu indeks yang digunakan untuk mengukur biaya pengeluaran rumah tangga dalam membeli kebutuhan hidup. 
b. Indeks Harga Produsen atau IHP, yaitu indeks yang digunakan untuk megukur biaya pengeluaran perdagangan besar seperti harga bahan baku, harga bahan mentah, atau harga bahan setengah jadi.

c. Indeks Harga Implisit atau IHI, yaitu mencakup jumlah barang dan jasa yang termasuk dalam hitungan Produk Nasional Bruto.

\subsection{Suku Bunga}

Secara umum, suku bunga dikenal oleh masyarakat di dalam dunia perbankan. Besaran persentase bunga tersebut tergantung dari besarnya pinjaman dan jangka waktu pinjaman. Suku bunga adalah harga yang harus dibayar si peminjam atas pinjaman dalam jangka waktu tertentu. Semakin rendah suku bunga pinjaman, maka masyarakat semakin bergairah dalam melakukan pinjaman dana. Begitu sebaliknya, jika suku bunga tinggi, maka masyarakat enggan untuk meminjam dana pada bank. Bank Indonesia memiliki suku bunga acuan yaitu BI Rate. Namun pada tanggal 19 Agustus 2016 diubah menjadi BI-7Day Repo Rate.

\subsection{Nilai Tukar}

Nilai tukar adalah harga mata uang suatu negara terhadap mata uang asing. Sebagai contoh, nilai tukar rupiah terhadap dollar pada akhir tahun 2017 sebesar Rp. 13.500, sehingga untuk mendapatkan 1 dollar maka kita perlu mengeluarkan uang rupiah sebesar Rp. 13.500. Nilai tukar dapat bergerak naik turun setiap harinya, dapat bersifat stabil dan labil. Pelemahan nilai tukar rupiah menandakan lemahnya kondisi untuk melakukan kegiatan ekspor-impor di negara Indonesia. Ini salah satu tugas Bank Indonesia sebagai Bank Sentral, yaitu menjaga kestabilan nilai tukar rupiah dengan cara menetapkan dan melaksanakan kebijakan moneter, serta mengatur dan menjaga kelancaran sistem pembayaran.

\subsection{Hipotesis}

Berdasarkan penjelasan literature diatas, maka hipotesis penelitian yang disusun oleh peneliti adalah sebagai berikut :

H1 : Jika inflasi meningkat, maka harga saham property menurun

H2 : Jika suku bunga meningkat, maka harga saham property menurun 
H3 : jika nilai tukar rupiah melemah, maka harga saham property menurun

\section{METODE PENELITIAN}

Penelitian ini menggunakan analisis regresi data paneli dengan sampel terdiri dari 7 perusahaan yang telah memenuhi kriteria. Metode pengumpulan data yang digunakan dalam penelitian ini adalah dokumentasi yaitu mencatat harga saham dari sampel penelitian setiap bulan pada tahun 2014 - 2018 yang tercantum pada laporan statistik bulanan di website resmi Bursa Efek Indonesia, mencatat data inflasi dan nilai tukar bulanan dari website resmi Bank Indonesia, dan data suku bunga yang diperoleh dari website resmi Badan Pusat Statistik.

Analisis regresi data panel, yaitu penggabungan cross section dan time series. Data cross section adalah data observasi pada beberapa subjek penelitian yang dikumpulkan dalam satu waktu, contohnya dalam satu tahun. Sedangkan data time series adalah data observasi pada satu subjek penelitian yang diteliti dalam satu periode waktu. Data cross section pada penelitian ini adalah terdapat 7 objek perusahaan sedangkan data time series pada penelitian ini terdapat 60 periode.

$$
Y i t=\alpha+\beta 1 X_{1} i t+\beta 2 X_{2} i t+\beta 3 X_{3} i t+\text { sit; }
$$

$i \quad=$ jumlah data observasi pada beberapa subyek penelitian, yaitu sebanyak 7 perusahaan

$t=$ jumlah data observasi pada beberapa periode waktu, yaitu 60 periode

$Y=$ Harga Saham

$X_{1}=$ Inflasi

$X_{2}=$ Suku Bunga

$X_{3}=$ Nilai Tukar

\section{TEMUAN-TEMUAN}

\subsection{Analisis Regresi Data Panel}

Regresi data panel dapat dilakukan dengan tiga model regresi antara lain common effect, fixed effect, dan random effect. Ketiga model tersebut memiliki kelebihan dan kekurangan masing-masing. Dalam regresi data panel, pemilihan model regresi tergantung dari asumsi peneliti dan pemenuhan syarat-syarat pengolahan data statistik yang benar, sehingga hasilnya dapat dipertanggungjawabkan secara statistik. Maka, langkah pertama yang dilakukan yaitu melakukan pemilihan model regresi yang paling tepat dari ketiga model tersebut. Dalam hal ini model 
terbaik yang digunakan adalah model fixed effect. Dengan demikian maka persamaan regresi data panel dengan model fixed effect dapat dilihat pada tabel dibawah ini

Tabel 1. Hasil Regresi Fixed Effect

\begin{tabular}{|c|c|c|}
\hline Variable & Coefficient & Prob. \\
\hline C & 2157.254 & 0.0000 \\
\hline X1 & -43.70286 & 0.0000 \\
\hline X2 & -14.63424 & 0.2145 \\
\hline X3 & -0.082580 & 0.0000 \\
\hline
\end{tabular}

Sumber: Data diolah penulis, 2019.

Dilihat dari tabel di atas, dapat dituliskan persamaan model analisis regresi sebagai berikut:

$\mathrm{HS}=2157,254-43,70 \mathrm{X} 1-14,63 \mathrm{X} 2-0,08 \mathrm{X} 3+\mathrm{e}$

Berdasarkan persamaan regresi data panel yang telah terbentuk di atas, berikut penjelasan dari persamaan tersebut:

a. Nilai konstanta sebesar 2157,254 . Apabila semua variabel bebas yaitu inflasi, suku bunga, dan nilai tukar rupiah diasumsikan bernilai 0 (nol), maka nilai harga saham subsektor property dan real estate sebesar 2157.

b. Jika inflasi mengalami kenaikan $1 \%$ maka harga saham akan menurun sebesar 43 dengan asumsi variabel lain bersifat konstan.

c. Jika suku bunga mengalami kenaikan $1 \%$ maka harga saham akan mengalami penurunan sebesar 14 dengan asumsi variabel lain bersifat konstan.

d. Jika nilai tukar rupiah mengalami kenaikan 1 rupiah per USD maka harga saham akan menurun sebesar 0,082 dengan asumsi variabel lain bersifat konstan.

\subsection{Uji Kelayakan Model}

Untuk mengetahui apakah variabel bebas inflasi, suku bunga, dan nilai tukar rupiah secara bersama-sama berpengaruh terhadap variabel terikat harga saham, 
maka dilakukan uji F. Berdasarkan model random effect menghasilkan uji hipotesis simultan atau uji $\mathrm{F}$ pada tabel di bawah ini:

Tabel 2. Hasil Uji F

\begin{tabular}{|c|c|}
\hline F-statistic & 359.7960 \\
\hline Prob(F-statistic) & 0.000000 \\
\hline
\end{tabular}

Sumber: data diolah penulis, 2019.

Hasil uji F pada table diatas menunjukkan nilai $\mathrm{F}$ hitung sebesar $359.7960>$ dari F tabel sebesar 2,626 dengan tingkat signifikansi $0,00<0,05$ artinya Ho ditolak dan Ha diterima. Kesimpulan dari hasil uji $\mathrm{F}$ bahwa inflasi, suku bunga, nilai tukar rupiah secara bersama-sama memiliki pengaruh signifikan terhadap harga saham perusahaan sub sekor property dan real estate di Bursa Efek Indonesia selama periode penelitian.

\subsection{Koefisien Determinasi}

Seberapa besar pengaruh variabel bebas (independen) terhadap variabel terikat (dependen) dapat diketahui dari besarnya nilai koefisien determinasi $\left(\mathrm{R}^{2}\right)$ yang berada antara nol dan satu. Nilai tersebut dapat dilihat pada hasil dari regresi panel model random effect. Dalam penelitian ini menggunakan lebih dari dua variabel bebas, maka koefisien determinasi yang digunakan adalah Adjusted $R$-Square. Berikut hasil perhitungan koefisien determinasi:

Tabel 3. Hasil Perhitungan Koefisien Determinasi

\begin{tabular}{|c|c|}
\hline R-squared & 0.887615 \\
\hline Adjusted R-squared & 0.885148 \\
\hline
\end{tabular}

Sumber: data diolah penulis, 2019.

Berdasarkan tabel di atas, menunjukkan nilai koefisien determinan (Adjusted $R$-Square) sebesar 0,885 yang artinya 88,5\% harga saham dapat dipengaruhi oleh variabel bebas inflasi, suku bunga, dan nilai tukar rupiah. Sedangkan sisanya $11,5 \%$ harga saham dipengaruhi oleh faktor-faktor lain di luar model penelitian. 


\section{DISKUSI}

\subsection{Pengaruh Inflasi Terhadap Harga Saham}

Uji parsial (uji t) antara variabel inflasi dengan harga saham menghasilkan kesimpulan bahwa inflasi memiliki pengaruh negatif yang signifikan terhadap harga saham subsektor property dan real estate yang terdaftar di Bursa Efek Indonesia periode 2014-2018. Artinya jika tingkat inflasi tinggi, maka harga saham akan turun, begitu juga sebaliknya. Hasil penelitian ini searah dengan penelitian yang dilakukan oleh Rosalyn (2018) yang mengungkapkan bahwa inflasi berpengaruh negatif secara signifikan terhadap harga saham.

Penelitian Efni (2009), menemukan bahwa tingkat inflasi mempunyai kemampuan pengaruh negatif yang signifikan terhadap harga saham subsektor property dan real estate. Inflasi yang tinggi dapat menyebabkan barang-barang mengalami kenaikan, termasuk biaya produksi, khususnya pada perusahaan properti. Inflasi juga dapat menyebabkan daya beli konsumen menjadi menurun akibat dari barang-barang yang semakin mahal. Kedua hal tersebut secara tidak langsung akan mempengaruhi kondisi pasar modal. Pendapatan masyarakat yang tidak sebanding dengan kenaikan barang, membuat masyarakat berhemat dan tidak tertarik dalam membeli saham, sehingga terjadi penurunan permintaan saham yang menyebabkan harga saham turun.

\subsection{Pengaruh Nilai Tukar Rupiah Terhadap Harga Saham}

Pada hasil estimasi fixed effect dengan uji t antara variabel nilai tukar rupiah dengan harga saham menghasilkan kesimpulan bahwa nilai tukar rupiah mempunyai pengaruh negatif secara signifikan terhadap harga saham. Artinya jika angka rupiah mengalami peningkatan (nilainya terdepresiasi) maka harga saham akan menurun. Begitu juga sebaliknya jika angka rupiah mengalami penurunan (nilainya terapresiasi), maka harga saham akan meningkat.

Hasil penelitian ini mendukung penelitian yang dilakukan oleh Budiantara (2012) yang menyimpulkan bahwa nilai tukar rupiah mempunyai pengaruh negatif secara signifikan terhadap indeks harga saham sektor properti. Serta penelitian yang dilakukan oleh Harsono dan Worokinasih (2018) yang menghasilkan kesimpulan yang sama. 
Pelemahan nilai tukar rupiah terhadap mata uang luar negeri (dollar Amerika) akan berdampak pada emiten atau perusahaan yang memiliki beban hutang dalam bentuk dollar Amerika dan perusahaan yang masih melakukan transaksi impor bahan baku dari luar negeri. Melemahnya nilai tukar rupiah menyebabkan jumlah beban hutang perusahaan menjadi lebih besar jika dinilai dengan rupiah dan meningkatnya beban biaya impor bahan baku. Hal ini berdampak pada penurunan laba perusahaan karena perusahaan akan lebih ekstra mengeluarkan biaya untuk membayar hutang dan biaya impor bahan baku. Laba yang rendah membuat deviden akan turun juga, sehingga investor tidak tertarik dalam membeli saham, karena deviden adalah salah satu faktor yang dipertimbangkan dalam keputusan pembelian saham bagi investor. Maka secara tidak langsung, dengan adanya pelemahan nilai tukar rupiah akan mengakibatkan penurunan harga saham.

Pada penelitian ini, pelemahan nilai tukar rupiah mempengaruhi penurunan harga saham pada subsektor property dan real estate, seperti pada harga saham Sentul City (BKSL), Bumi Serpong Damai (BSDE), dan Modernland Realty (MDLN) yang melakukan perdagangan impor bahan baku / bahan kontruksi seperti kayu olahan, cat, pelitur, vernis, material konstruksi, kaca datar, ubin dan lain-lain. Perusahaan-perusahan tersebut juga memiliki hutang luar negeri dalam bentuk mata uang asing, sehingga menyebabkan pendapatan lebih banyak digunakan untuk membayar hutang dalam mata uang asing akibat dari rupiah yang melemah. Lippo Karawaci dan Summarecon Agung juga mengalami hal yang sama. Kondisi tersebut membuat pencapaian laba lebih sedikit dan pembagian deviden pun sedikit. Hal ini menyebabkan investor kurang tertarik berinvestasi pada saham subsektor property dan real estate. Kurangnya peminat saham menyebabkan kinerja subsektor property dan real estate menurun, sehingga harga saham mengalami penurunan.

\subsection{Keterbatasan}

Penelitian ini mengimplikasikan bahwa sebaiknya investor memperhatikan faktor-faktor ekonomi makro seperti tingkat inflasi dan nilai tukar rupiah sebagai pertimbangan dalam keputusan pembelian saham yang dalam penelitian ini berpengaruh signifikan terhadap harga saham. Perusahaan subsektor property dan 
real estate yang terdaftar di Bursa Efek Indonesia terus menjaga harga saham tetap stabil agar masyarakat atau investor memiliki minat untuk berinvestasi pada saham subsektor property dan real estate.

Selanjutnya penelitian ini dapat dikembangkan pada sektor lain, sehingga mengetahui sektor mana saja yang tahan dan rentan terhadap ketidakstabilan kondisi ekonomi makro. Selain daripada itu, penelitian selanjutnya dapat menambahkan jumlah sampel penelitian lebih banyak dari penelitian ini dan menggunakan metode analisis lain yang dimungkinkan lebih baik sehingga memperoleh hasil penelitian yang lebih akurat.

\section{DAFTAR PUSTAKA}

Budiantara, M. (2012). Pengaruh Tingkat Suku Bunga, Nilai Kurs, dan Inflasi, Terhadap Indeks Harga Saham Gabungan di Bursa Efek Indonesia Periode Tahun 2005-2010. Jurnal Sosiohumaniora, 3(3).

Efni, Y. (2009). Pengaruh Suku Bunga Deposito, SBI, Kurs, dan Inflasi Terhadap Harga Saham Perusahaan Real Estate dan Property di BEI. Jurnal Ekonomi, 17(1).

Harsono, A., \& Worokinasih, S. (2018). Pengaruh Inflasi, Suku Bunga, dan Nilai Tukar Rupiah Terhadap Indeks Harga Saham Gabungan. Jurnal Administrasi Bisnis, 60(2).

Hidayat, R. (2014). Peluang dan Tantangan Investasi Properti di Indonesia. Jurnal Akuntansi UNESA, 2(2).

Jayanti, Y. (2014). Pengaruh Tingkat Inflasi, Tingkat Suku Bunga SBI, Nilai Tukar Rupiah, Indeks Dow Jones, dan Indeks KLSE Terhadap Indeks Harga Saham Gabungan. Jurnal Administrasi Bisnis, 11(1).

Kasmir. (2017). Bank dan Lembaga Keuangan Lainnya (Revisi 2014 ed.). Jakarta: Rajagrafindo Persada.

Kewal, S. (2012). Pengaruh Inflasi, Suku Bunga, Kurs, dan Pertumbuhan PDB Terhadap Indeks Harga Saham Gabungan. Jurnal Economia, 8(1).

Mardiyati, U., \& Rosalina, A. (2013). Analisis Pengaruh Nilai Tukar, Tingkat Suku Bunga, dan Inflasi, Terhadap Indeks Harga Saham. Jurnal Riset Manajemen Sains Indonesia, 4(1).

Muamil, S., \& Rudi, L. (2018). The Effect of Macroeconomic Variables on Banking Stock Price Index in Indonesia Stock Exchange. Russian Journal of Agricultural and Socio-Economic Sciences, 78(1).

Muchlas, Z., \& Alamsyah, A. (2015, Februari). Faktor-Faktor Yang Mempengaruhi Kurs Rupiah Terhadap Solar Amerika Pasca Krisis (2000-2010). Jurnal Jibeka, 9(1). 
Natsir, M. (2014). Ekonomi Moneter \& Kebanksentralan (1 ed.). Bogor: Mitra Wacana Media.

Nugroho, P. W., \& Basuki, M. U. (2012). Analisis Faktor-faktor yang Mempengaruhi Inflasi di Indonesia Periode 2000:1-2011:4. Diponegoro Journal of Accounting, l(1).

Rahardja, P., \& Manurung, M. (2008). Pengantar Ilmu Ekonomi (Mikroekonomi \& Makroekonomi) (3 ed.). Jakarta: Fakultas Ekonomi Universitas Indonesia.

Rosalyn, A. M. (2018, June). The Effect of Rupiah Exchange Rate and Inflation Rate Towards Composite Stock Price Index in Indonesia Stock Exchange. Russian Journal of Agricultural \& Socio-Economics Sciences, 78(6).

Simbolon, L. P. (2018). The Influence of Macroeconomic factors on Stock Price : The Case of Real Estate and Propertty Companies. Research in Finance, 34.

Umam, K. (2013). Pasar Modal Syariah dan Praktik Pasar Modal Syariah. (B. A. Saebani, Ed.) Bandung: Pustaka Setia.

Wijaya, R. (2013). Pengaruh Fundamental Ekonomi Makro Terhadap Indeks Harga Saham Gabungan Pada Bursa Efek Indonesia Periode 2002-2011. Jurnal Ilmiah Mahasiswa Universitas Surabaya, 2(1).

\section{Sumber Lain}

http://www.bi.go.id http://www.bps.go.id http://www.idx.co.id http://www.finance.yahoo.com 